\title{
MITOCHONDRIAL COMPLEX I PROTEIN IS RELATED TO RESIDUAL FEED INTAKE IN BEEF CATTTLE
}

\author{
Marcelo Hentz Ramos
}

Monty Kerley, PhD., Dissertation Supervisor

\begin{abstract}
Residual feed intake (RFI) is a calculated using DMI as dependent variable and metabolic body weight $\left(\mathrm{BW}^{0.75}\right)$ and $\mathrm{ADG}$ as independent variable. Mitochondria complex I (mitochondrial NADH:ubiquinone oxidoreductase) is one of the least understood membrane bound protein complexes. Insulin resistance has been reported in calves, dairy cows, horses and swine. For all four mitochondria experiments, there was a significant difference $(\mathrm{P}<0.05)$ between RFI and DMI but no difference $(\mathrm{P}>0.05)$ was reported for $\mathrm{ADG}$ and $\mathrm{MMBW}$. For experiments one, two and three, CI was greater $(\mathrm{P}<0.05)$ for $-\mathrm{RFI}$ compared to other treatments. The correlation between $\mathrm{CI}$ and RFI was $-0.37(\mathrm{P}=0.02),-0.48(\mathrm{P}=0.034)$, and $-0.84(\mathrm{P}=0.015)$ for experiment one, two and three, respectively. For experiment 4, animals with -RFI had a trend for greater concentration $(\mathrm{P}=0.07)$ of Band I (protein S1) than + RFI. Correlation between RFI and Band I was $-0.72(\mathrm{P}=0.04)$. A regression was developed using Band I and RFI with RFI $=6.1715-0.00015$ Band $\mathrm{I}, \mathrm{R}^{2}=0.85, \mathrm{RMSE}=0.62$. No significant difference $(\mathrm{P}>0.05)$ was reported in any variable measured during both the glucose and epinephrine tolerance test. We concluded that mitochondrial function was at least in part responsible for differences among animals in metabolic efficiency. In addition, insulin resistance is not responsible for RFI classification in feedlot animals.
\end{abstract}


